\title{
A CRITICAL STUDY ABOUT THE EFFECTS OF BLOOM'S TAXONOMY IN THE CONTEXT OF ENGLISH LANGUAGE TEACHING AT UNIVERSITY LEVEL
}

\author{
Salma Niazi \\ Lecturer, \\ Department of English, Jinnah University for Women, \\ Sindh, Pakistan \\ Email: salmasaqib79@gmail.com

\section{Farida Azim Lodhi} \\ Professor, \\ Department of Education, Jinnah University for Women, \\ Sindh, Pakistan \\ Email: faridalodhidr@hotmail.com \\ Huma Mahmood \\ Research Scholar, \\ Department of Education, Jinnah University for Women, \\ Sindh, Pakistan \\ Email: humasalman80@gmail.com
}

\begin{abstract}
The purpose of this study was to critically analyze the effectiveness of Bloom's taxonomy of educational objectives, in teaching English language at university level in Karachi, Pakistan. The conceptual framework of the study, included the results of two groups of English language learners that were independent and controlled group. For the current study quantitative research design was used. The population was English language teachers and students of English Department, those were sixty. Stratified sampling was used to extract the research sample. A well-designed test containing twenty-five marks was constructed, to get the achieved outcome of language teaching and learning. It was concluded that incorporating Bloom's objectives of teaching would be able to improve English language learning among students at tertiary level. It was recommended that teachers training workshops should be arranged for English language teachers, so that they may enhance their knowledge about teaching critical thinking while incorporating Bloom's objectives of teaching methodology, that may be benefitted both language learners and research in the field of English language learning in Pakistan.
\end{abstract}

\section{KEYWORDS}

Critical Thinking, Effective pedagogical approaches, Bloom's taxonomy

\section{INTRODUCTION}

Teaching and learning is as old as history itself; turn the pages of history and find the 
pages are full of eminent personalities who were teachers. Teaching is an art because it involves emotions. It is not as initiating a synthetic response, it is significantly more like painting an image, or making a bit of music, or one like planting a nursery for enriching a jar or composing a well-disposed letter, that one should toss heart into it. A viable educator is one who augments the accomplishments of understudies by acting per an express arrangement of rules that have request, intelligibility, and pertinence in the specific instructional setting.

The Government of Pakistan and the Ministry Of Education worked with the help of the USA and developed the National Educational and Professional Standard for Teachers' Education in Pakistan. The standards contained many practical skills such as leadership skills, English language communication skills, dual- language skills, spiritual development, and social identity. Out of all these skills English language communication skill is of utmost importance as it would enable students to live and grow in the English speaking community

This research aims to explore the insights that can inform teachers on issues of current concern, for example, the design of curriculum which has as a primary goal in the development of communicative ability in learners and designing classroom procedures for effective development of language skills. Higher Education Commission of Pakistan is also very enthusiastic about English language communication because better English means better job opportunities. With the advancement of science and technology, globalization is blurring the boundaries of the countries; it is a word that represents a challenge to the 21st-century generation as well as it is allowing the living and working in English speaking society. In emerging countries like Pakistan, Kenya, Bangladesh, Srilanka, Malaysia, English is acting a dominating role in building and driving the economy, it is very important to learn the English language. Furthermore, English is also facilitating subject matter knowledge and ultimately preparing students for their professional field in the future... Bloom's taxonomy incorporated English language teaching improves student's content learning as well as their language skills. There is a direct relationship between instructing English and Bloom's Taxonomy.

English is non-native language in Pakistan and the students are afraid of speaking in and outside the classroom but if the teacher is wise enough to follow Bloom's objectives then guidance of English will be fun and pleasing activity. Students are no more considering English language learning as a difficult task but an opportunity to learn fast. Bloom's objective of teaching and learning if handled wisely in the context of English language teaching, accelerates learning.

Effective teachers with effective classroom practices have shown to improve their intended learning outcomes. It will improve the learning of the students and prepare them to face many challenges in terms of English language speaking. Students are the major driving force in developing countries. Students are driving the economy and future of Pakistan.

Harmer, (2007) defined the teacher metaphorically as an actor playing many roles. It 
appears as they are the actors on stage and performing their roles on the stage and just feel themselves as they are always on the stage. Then he gives an example of gardeners as they are planting the seeds and then watching them grow and it is the teacher who is not only imparting knowledge but also facilitating knowledge in the learning environment. He/She is also a friend and creates a harmonious environment so that language learning is no more a difficult task, but it becomes fun. It is the part of a teacher that he/she is turning teaching language into fun. She/he is a planner and she organizes many language learning activities in the classroom. She/he is the leader and also a facilitator. He/ She is the controller. Teachers are leading from the front and they are transferring the knowledge by charismatic character. First of all, he/she is inspiring and then igniting the thirst for knowledge in their students with a sense of leadership. She/he is also a prompter; he/she ignites in them thirst for learning new words from the vocabulary. Because it is the language learning class, so he/she is facilitating language learning keeping in view the objectives of Bloom's taxonomy. She/he is also a participant in the classroom. She/he is a resource person and according to Harmer teacher is the best resource in the classroom. The teacher is performing many roles in the classroom; who engages them and instructs the students how to speak and what to speak with the help of demonstration. He/she initiates learning and then language learning. The teacher imbibes in their learners' autonomy. For example, he/ she is performing an activity for teamwork as a game energetically. She/he is encouraging them clearly and fairly. Again he/she is playing the role of encouraging them and also supporting students. Rapport is also the best part of the classroom in language learning as per Bloom's affective objectives of teaching and learning and the affective domain is also very important in the classroom. By knowing the names of the students it is good to memorize all the names of the students so it creates a sense of friendliness and establishment of rapport which is good. It also involves knowing about what students want their teachers to know, who they are and what they would like. They want their teachers to know them by their names and listen to them. If we listen to them, they feel being respected. It is the responsibility of a teacher that the students being treated evenhanded, and respond equally do not point out anyone student. Professionally, all students are treated equally.

English is educated as a subject in our schools from class one to class eight and as a mode of guidance in optional classes however research has indicated that when the understudies join the college, he/she scarcely knows 1500 words and he/she can't utilize it successfully in everyday correspondence. It will be wrong to attribute this failure to anyone's particular problem infraction; many problems confront us and various factors are contributing to that failure. It is wrong to blame a single issue. But out of various contributing factors of lack of English speaking among students, the dominating factor is teachers' inability to shoulder the responsibility of their professional grooming.

There are many challenges that the teachers face in language skills at the university level. Among the issues raised was the degree of learning outcomes achieved by the learners, particularly when it comes to curriculum adjustment, which emphasizes the achievement of the higher level of thinking skills or HOTS as extracted from the cognitive learning domain taxonomy of Bloom, which was presented in 1956 and later 
revised in 2001. The cognitive domain is effective in assessing higher order of thinking of English language learning.

The study sheds light on the effectiveness of Bloom's taxonomy in the context of English language teaching at the university level, with the help of two English language learning groups.

\section{LITERATURE REVIEW}

\section{English Language Teaching and Learning}

Cultivation of language is dynamic process. Method refers to the reasons of the course of action related to instruction. It instructs the way of teaching and manners of effective teaching. The most important factor for an instructor is to grasp the manners and strategies of teaching English. Anthony, (1963) defined method as: The cycle of lesson planning, selection of the topic and preparation of instructional situation is regarded as method .He then added further definition of method as: the specific way of attaining the learning objective and the endeavors with a particular theory is regarded as a method. Mackey,(2011) stated that: A method comprises of four elements, The selection of content, the analysis of content, the way of demonstration and the practice.

Teaching methods are divided as:

In Grammar Translation Method rules of grammar are explained with the help of sentences. The sentences by following the principles of grammar translated from Urdu to English. GTM starts with the translation of words and sentences. But translation method kills spontaneity. GTM gives mastery over vocabulary, but it gives no emphasis over skills. GTM is insufficient for the mastery of language skills.

Audiolingual relied heavily on practices. The purpose of Audio lingual teaching is to reduce the speaking mistakes of English language learners by repetition. But this reinforcement of constant repetition encourages speaking and improves listening skills, but there is no emphasis for reading skill and writing practices.

In Pakistan, English language is not the most frequently used language of this country and the primary source of education and economy. In educational institutes, English is mandatory and is included as a compulsory subject. According to Dong (2016) English has become a global tool for communication and has become a part of economy. Major aim of teaching language is to facilitate English language practices and enhance their communication skills through the usage of effective teaching methods in colleges and universities to make good educational environment.

Moreover, Lectures remain the effective approach for the classroom teaching. It has been confirmed that lectures are more interesting and develops the involvement of students in classroom.

Thomson (2012) has identified the techniques and strategies to be used by the teacher to make the students learning effective. He concluded that teachers should be aware to about the techniques and strategies in order to implement in classroom and make the 
relationship between teacher and student more powerful.

Furthermore, Awan and Shafi (2016) have explored the interest of students and concluded that they prefer Urdu language rather than English language teaching. They usually like to communicate in Urdu instead of English. They have favored GTM rather than Direct Method (DM). Moreover, they, have stated that through GTM teaching English is easier and more demandable. Students are satisfied to be taught and learned through this method of teaching language. Through, this point of view of students, researchers have found this method effective. However, Hussain, Inamullah, Naseerud-din and Hafizatullah (2009) have mentioned in their research that direct method is more effective teaching methodology rather than GTM. DM has been found more worth able for lower level students as it provides them more opportunities to communicate and interact socially in English language.

Language teachers have experimented certain types of language teaching methods in combination and isolation and have found one or more than one methodology as an effective teaching method which is worth using (Shaikh, 2013). It is hard to state what procedure of instruction is more effective and more valuable than others. Usage of methods should be based on classroom needs, requirements, intellectual of individual, learning experience,social foundation of learners and mentalities towards showing English as a subsequent language(Shaikh, 2013).

Most of the researches have been conducted intentionally on techniques of teaching English language, strategies, analysis of students' perceptions, importance of grammar translation method GTM and DM and many more methods like cooperative approach (CL), communicative language teaching (CLT), lecture approach, group discussion approach etc. and to find out the effective teaching methodology for teaching English, at tertiary level in Karachi.

Eclectic approach is used for teaching a language in which the teacher teaches students with different methods and techniques for the development of students learning abilities according to their needs. As, Tare (2016) has stated that teaching and learning requires creativity and innovation in learning strategies and techniques and there are lots of different methods that can be applied in the classroom for better learning of the students.

Ellis, (2012), pointed out that there are various strategies of guidance English language. Each method contradicts and negates the previous methodology. Each of these have merits and demerits. There are various circumstances in educational institutes in which it is impossible for a language teacher to follow one methodology or the others. As there are overcrowded classrooms and time is another important hindrance for language teachers. None of the method is perfect in every respect and thus it is the mastery of teacher, and analysis of the situation that shapes learning experience. Killen, (2009), suggested that quality teaching depends upon the effectiveness of the teacher and teaching objectives. According to (Hattie, 2012) it is much more important to encourage students to think critically. Cole and Chan 1986 recommended that a powerful educator 
is one who augments the accomplishment of the understudies by basic reasoning, hencebasic reasoning is the most significant skills to master and at is the most important methodology to follow for language teaching. Critical thinking the most significant technique to follow for language instructing in the 21st century. These skills, are not new as they were included in the taxonomy of objectives presented by Bloom in 1956 . Literature is crammed full with the fact that teaching effectiveness is directly related with the uplifting of critical thinking of the learners, (Murray, 1994)

Language is our social device. We use it to share understanding thus to all things considered, mutually, comprehend it ... Language is a method by which people create innovative ideas and share experiences in a society (Gibbons, 2016).

\section{Bloom's Taxonomy}

Teaching and learning encompasses a vast canvas, potentially covering many challenges that affect the learners' stages of learning. Teaching and learning the important factor in encompassing educational objective. John Dewey held that the processes of instruction should be based on critical thinking. He believed that best teachers are the reflective thinkers and he was against traditional practices. According to him knowledge is not transmitted but offered. Dewey's meaning of instruction as that the recreation or revamping of experience which adds to the significance of experience and which increment capacity to coordinate the course of ensuing experience. Thus Dewey's ideal of learner is continuously inspiring towards change, socially responsible being and they are contiguous with the ideal responsible citizen of a society.

As compare to other communication skills for example reading and writing, critical thinking is not an instinct or natural skill, it is developed with the guidance of more knowledgeable person or a teacher. According to Tanner \& Tanner (1980) speaking is a skill and we exercise the skill by nature but critical thinking skill is not an instinctive skill, it is not a deliberately developed skill, rather it is developed by some external motivation. Teachers play a pivot role in building critical thinking.

It is important for teachers to integrate critical thinking in their language teaching as a teacher is the most dominating agent in a class room and he/she brings the change in the learning behaviors of the student. Students' clear understanding and knowledge judged at the end of the course. Bloom's Taxonomy incorporated with English language teaching improves students' content learning as well as their language skills. There is a direct relationship of English language teaching and Bloom's taxonomy.

English is the non-native language in Pakistan and the students are afraid of speaking in and outside the classroom, but if the teacher is wise enough to follow Bloom's objectives then English language teaching and learning will be fun and a pleasing activity .Students are no more considering English language learning as a difficult task but an opportunity to learn fast. Bloom's objective of teaching and learning, if handled wisely in the context of English language teaching accelerates learning.

Bloom's Taxonomy was published by Benjamin Bloom 1956 and is an excellent way to 
categorize the stages of learning skills related to the classrooms. Bloom's taxonomy is a classification of the stages of critical thinking skill.

\section{Knowledge}

This stage of classification belongs to the lower order of thinking skill. In this stage teaching methodology is based on the previous knowledge of the students. For instance, have they remembered the dates for a specific occasion? Or then again do they know the presidents that served during explicit time in Pakistan. It additionally incorporates information on the fundamental thoughts that are being educated to understudies. The activity action words of this stage are words like tell, list, name, and so on.

\section{Comprehension}

The second stage of Bloom's taxonomy makes learning easier .At this level they simply recalling facts and with the understanding they solve the problems. At this stage teacher as a facilitator is performing in the classroom. For example how to construct sentences are guided at this stage .They are probably writing comprehension questions by action words like describe, contrast, discuss, predict, etc.

\section{Application}

Application means to apply, or to use of the understanding they have gained. For example they have learnt the rules of tenses and now they are using the rules in the dialogues and conversation. The action verbs are: complete, solve, examine, illustrate, show, etc.

\section{Analysis}

This stage belongs to higher order of thinking skill. At this stage students are synthesizing the complex paragraphs and texts. They are probably writing analysis questions. The action verbs of the stage are: analyze, explain, investigate, infer, etc.

\section{Synthesis}

At this stage of learning students are able to formulate innovate ideas. Their ability to discern facts and issues is highly developed. They are writing articles based on creativity by using words like invent, imagine, create, compose, etc.

\section{Evaluation}

Assessment is the higher order of reasoning or critical skill. This stage is at the pinnacle of the scientific categorization. At this stage understudies are with exceptionally evolved reasoning and basic aptitudes. They can take choices. The activity action words of this stage are words like select, judge, banter, suggest, and so on.

It is fundamentally significant that we as teachers help our understudies become basic scholars. Expanding on information and helping kids start to apply, break down, integrate, and assess is that the way to helping them develop and succeed in class and past. This was reported in Taxonomy of Educational Objectives (1956) edited by Benjamin S. Bloom. An attempt was made to identify and classify all possible educational outcomes. In this system the objectives are divided into three major areas; 
The Cognitive or domain based on intellect includes:

Knowledge

Comprehension

Application

Analysis

Synthesis

Evaluation

The affective domain includes:

Receiving

Responding

Valuing

Organization

Characterization of a worth complex

The psychomotor domain incorporates:

Reflex developments

Fundamental developments

Perceptual capacities

Physical capacities

If we look at the model of parameters of cognitive domain we find it that it is like the shape of a pyramid, as it is from general to specific .The levels are broad at the base and narrowing at the peak.
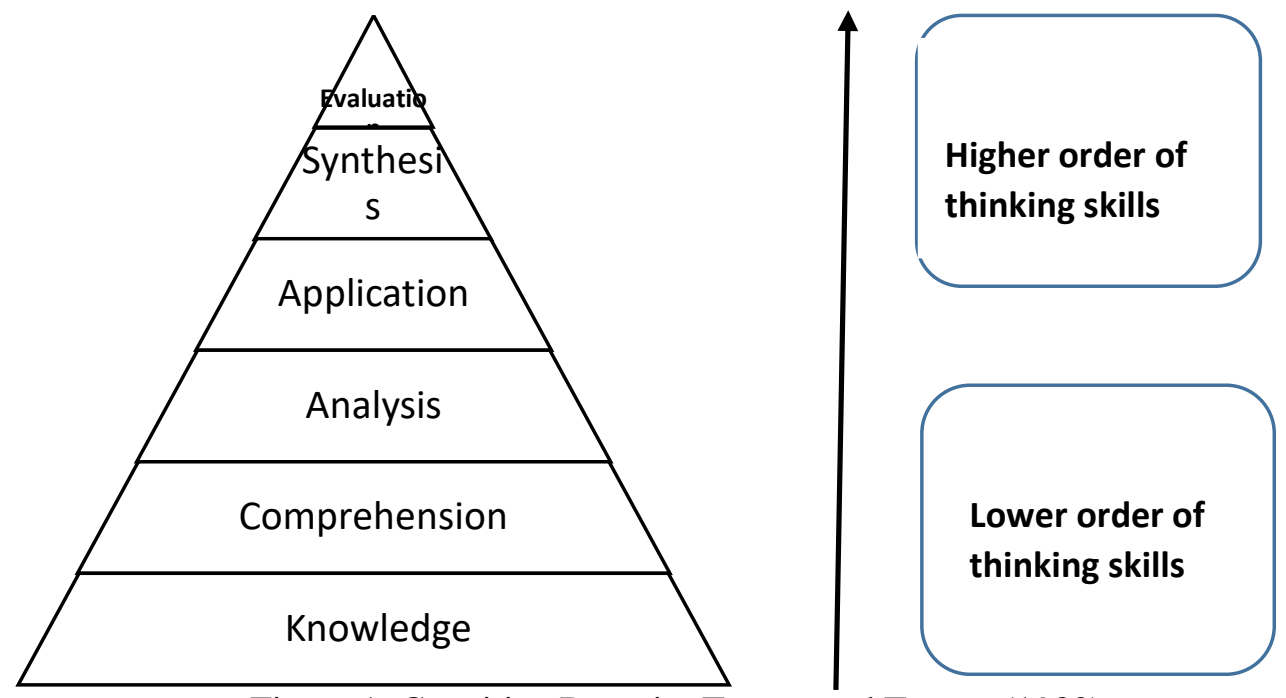

Figure 1: Cognitive Domain, Tanner and Tanner (1980)

\section{Cognitive domain}

The reason of this pyramid shape is that the levels are moving from lower order of thinking skills. It is the part of a language teacher that she/he is facilitating language learner from lower stages of critical thinking to higher stage of critical thinking .it is as 
if guiding a child how to walk and he is gradually taking the steps. Or we can give the example of food the food suitable for the digestion of a little kind is different from the food of a grown up and adult, same is the condition of a languages learner, over here a languages instructor following Bloom's classification and level gradually guiding a learning . Take the example of action verbs related with each stage;

\begin{tabular}{|c|c|}
\hline 1 Knowledge & Write \\
\hline & Enlist \\
\hline & Identify \\
\hline & Define \\
\hline & Basics \\
\hline 2 Comprehension & Explain \\
\hline & Elaborate \\
\hline & Discuss \\
\hline & Comment \\
\hline & Describe \\
\hline & Rephrase \\
\hline 3 Application & Use \\
\hline & Solve \\
\hline & Apply \\
\hline & Drive \\
\hline 4 Analysis & Compare \\
\hline & Differentiate \\
\hline & Distinguish \\
\hline & Analyse \\
\hline & Create \\
\hline 5 Synthesis & Formulate \\
\hline & Design \\
\hline & Devise \\
\hline & Assemble \\
\hline 6 Evaluation & Justify \\
\hline & criticize \\
\hline & Summarize \\
\hline & Appraise \\
\hline & Support \\
\hline & Value \\
\hline & Evaluate \\
\hline
\end{tabular}

\section{Affective Domain}

As mentioned by Tanner and Tanner (1980), no matter whatever be the methodology of teaching English language in a class room the most important factor is to consider the active verbs of each level. It is good if mention the level of learning to the student. There are various language teaching methods in the context of English language teaching: 
1) Grammar-Translation method

2) The direct method

3) Situational method

4) Communicative method

5) The bilingual method

6) Elective approach

It is the teacher who is guiding that English language. That is why the course is known as ELT, English Language Teaching. According to J.F. Kerr Curriculum is the learning which is planned and guided by school whether it is carried out individually or in a group, inside or outside the school. Johnson suggested "curriculum is a structural series of intended learning outcome."

Dewey (1998) developed the concept of curriculum and held the concept that the processes of instruction should be based on critical thinking. He believed that best teachers are the reflective thinkers and he was against traditional practices. According to him knowledge is not transmitted but offered. Dewey's definition of education as that 'the reconstruction or reorganization of experience which adds to the meaning of experience and which increase ability to direct the course of subsequent experience'. Thus, Dewey's ideal of learner is continuously inspiring towards change, socially responsible being and they are contiguous with the ideal responsible citizen of a society. He believed teachers are in a commanding situation in an educational institute. The most dominant role is played by the teacher. There are four important components of a curriculum:

1) Objectives

2) Content

3) Learning experiences/methodology

4) Evaluation

Three domains of objectives are:

1) Affective domain

2) Psychomotor domain

3) Cognitive domain

Today in the age of technology. There are various sources of information in the form of modern media resources available that are enhancing knowledge and understanding of a student. So, students have highly developed and focus cognitive learning but they lack the affective domain. All learning is based on affective domain. Affective domain deals with emotions, feelings, attitude and heart.

There are five levels of affective domain.

\section{Receiving}

Receiving is connected with the law of readiness.it is the role of a teacher that how she/he is transforming students' mode into receiving mode. Teacher enters in a class room with a smiling face and then she /he probes the questions. The teacher introduces the significance of the topic. Teacher because of his /her knowledge of the subject having the confidence and command of the subject. They build a rapport with the 
students. Now students are ready for response.

\section{Responding}

Because of the rapport and readiness to learn students are willing to give response.

\section{Valuing}

As the students respond they realize the value of learning. The worth of knowledge is clear in front of them, their vision is clear. There is commitment in their work. They prepare the acquisition of learning. Then the learners attain the higher order of learning/thinking skills (HOTS).

The affective domain of learning objective gives a sense of ownership of learning to the learners. Learning is the chief bliss for them. They attain learner's autonomy they are at the stage of self-actualization and they are self-directed. Learning is at its peak. As recommended by Tanner and Tanner (1980), objectives stand from teachers' side. It involves process and product outcomes. Curriculum basically has general objectives but how to convert general objectives into specific outcomes is the expertise of a teacher. In the past, teaching was content based on objectives with defined action verbs. It is the mastery of a teacher to convert the learning from difficult to easy and from general to specific the weapons are action verbs for all stages of learning. Perception is the most important factor.

\section{Psychomotor Domain}

Psychomotor domain talks about physical ability, coordination and motor skills motor skills are fine and gross. Psycho means mind and motor means movement of muscles. Fine skill involves reading and gross skills are high level activities for example presentation and teaching. Perception is linked with brain. As our brain takes inspiration from the teachers. Students are inspired by the knowledge and learning or speaking skill of a teacher. Then because of their interest they receive signals from their brain and they imitate or copy their teacher. Students have in front of them are examples and now the mechanism activate and they copy the mentors.

\section{THEORETICAL FRAMEWORK}

The variables in teaching methodology and achieved marks were implemented to analyze the relevance of Bloom's taxonomy of educational objectives on teaching of English language among students at university level. Teaching methodology was independent variable, whereas marks were dependent variable.

The research was quantitative in nature. To compare the means of two groups of English language learners' independent $t$ test was applied using SPSS. The participants included two English language teachers who were teaching two groups of English language learners. The group A was taught as per Bloom's objectives of teaching whereas the methodology of group B language teacher was not focusing on Bloom's objectives.

\section{RESEARCH OBJECTIVE}

1. To investigate the impact of the cognitive domain, consisting of six levels on English language teaching at the university level. 
2. To determine the influence of the affective domain, consisting of five levels, on English language teaching at the university level

3. To analyze the reaction of the psychomotor domain, consisting of six levels on English language teaching at the university level.

4. To identify English language teaching practices at the university level.

5. To analyze the implications of Bloom's Taxonomy incorporated English language teaching at the university level.

\section{RESEARCH QUESTIONS}

1. Is Bloom's taxonomy relevant to be the basis of teaching the English language?

2. Why is it important to incorporate Bloom's objective of teaching while teaching the English language?

3. Is it important to analyze Bloom's taxonomy and study its relevance to the teaching of English?

4. Would adopting Bloom's objective of teaching be rewarding and would the findings be helpful in curriculum development and helpful for the teachers to attain the desired objectives of the course?

\section{RESEARCH METHODOLOGY}

The reason of the study is to critically analyze the effectiveness of Bloom's objectives of teaching on English language learning at tertiary level. (Dornyei, 2011)The quantitative study was applied in nature and in order to collect the data an experiment has been designed.

The study represented quantitative research as it was established cause- effect relationship. In real life nothing happened in isolation and it was hard to disentangle the interferences of various related factors. Taking the data collection procedures the study contained groups, the experimental group and the controlled group. Experimental group was labeled as group A, whereas controlled group was labeled as Group B. For group A, the teaching strategy was based on Bloom's objectives of teaching methodology, whereas group B teaching methodology was not based on Bloom's objective of teaching. After the teaching of three months, the progress of both groups was measured by a test. The test was pre-formulated by the researcher and it carried twenty five marks. The marks were obtained by the students to indicate their learning progress. Validity, reliability and ethical considerations were considered .The comparison of two groups were carried out by applying Independent-samples t-test.

Independent-samples t-test was for research design where the researcher was comparing the results of two groups that were independent of each other for example in the study, the teaching strategy of group A was independent of that of group B. group A was following Bloom's objective of teaching and learning methodology whereas group B was not following Bloom's objectives of teaching and learning methodology. One variable in this study involved marks obtained by the students in the English language test and the grouping variable was teaching methodology. Then examined whether there was a significant difference between group A and group B, to do so the researcher needed to compute the independent-samples t-test. The data were analyzed by SPSS 
needed to compute the independent-samples t-test. The data were analyzed by SPSS version 20 applying independent-samples t-test.

English language teachers were two at university level and a group of English students were sixty. All the students of BS II English Compulsory Classes were included in the study.

The sampling was probability sampling following the procedure of stratified sampling the students of BSII of two different departments were selected in English compulsory classes. Out of seventeen, two English language teachers were selected as sample. One teacher's methodology was based on Bloom's objectives while second teacher was not following Bloom's objectives. Two groups of sixty students (thirty + thirty) were formed as sample. A test of twenty-five marks was designed in order to measure the progress of English language teaching and learning.

According to the paradigm of the study independent samples t-test proved to be the most appropriate statistical test in order to highlight the difference between the teaching methodologies of two groups, group A and B. The study contained two groups the treatment or experimental group and the controlled group. Experimental group was labeled as group A, whereas controlled group was labeled as Group B. For group A, the teaching strategy was based on Blooms objectives of teaching methodology, whereas group B teaching methodology was not based on Bloom's objective of teaching. After the teaching of three months, the progress of both groups was measured by a test. The test was pre -formulated by the researcher and it carried twenty five marks. The marks obtained by the students indicated their learning progress. Validity, reliability and ethical considerations were considered .The comparison of two groups were carried out by applying Independent-samples t-test. The obtained data was computed by SPSS version 20 applying independent samples t-test.

Results were interpreted following Levene's test.

The decision of Levene's test indicated that if $p$ was less than 0.05 the variances were significantly different. Following was the analysis and the interpretation of independent samples t-test: The means were interpreted as follows; mean of group A is 24 and group $\mathrm{B}$ was 19. The difference between two means was significantly low. The mean was 24 and for group A and the mean of the group B that was the group not following the objectives of Bloom's taxonomy was 19 , the difference between the two means was five.

\section{FINDINGS \& RESULTS}

Table4.1 SPSS Independent Samples t-Test

\begin{tabular}{ccccccc}
$\begin{array}{c}\text { Levene's Test } \\
\text { for Equality of } \\
\text { Variances }\end{array}$ & \multicolumn{5}{c}{ t-test for Equality of Means } \\
\hline F Sig. & T & Df & $\begin{array}{c}\text { Sig. } \\
2-\end{array}$ & $\begin{array}{c}\text { Mean } \\
\text { Differen } \\
\text { taile }\end{array}$ & $\begin{array}{c}\text { Std. } \\
\text { ce }\end{array}$ & $\begin{array}{c}\text { Error } \\
\text { Interval of the } \\
\text { Difference }\end{array}$ \\
\hline
\end{tabular}


PJER, Vol 4, Issue 2 (2021)

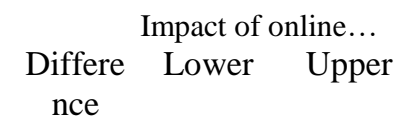

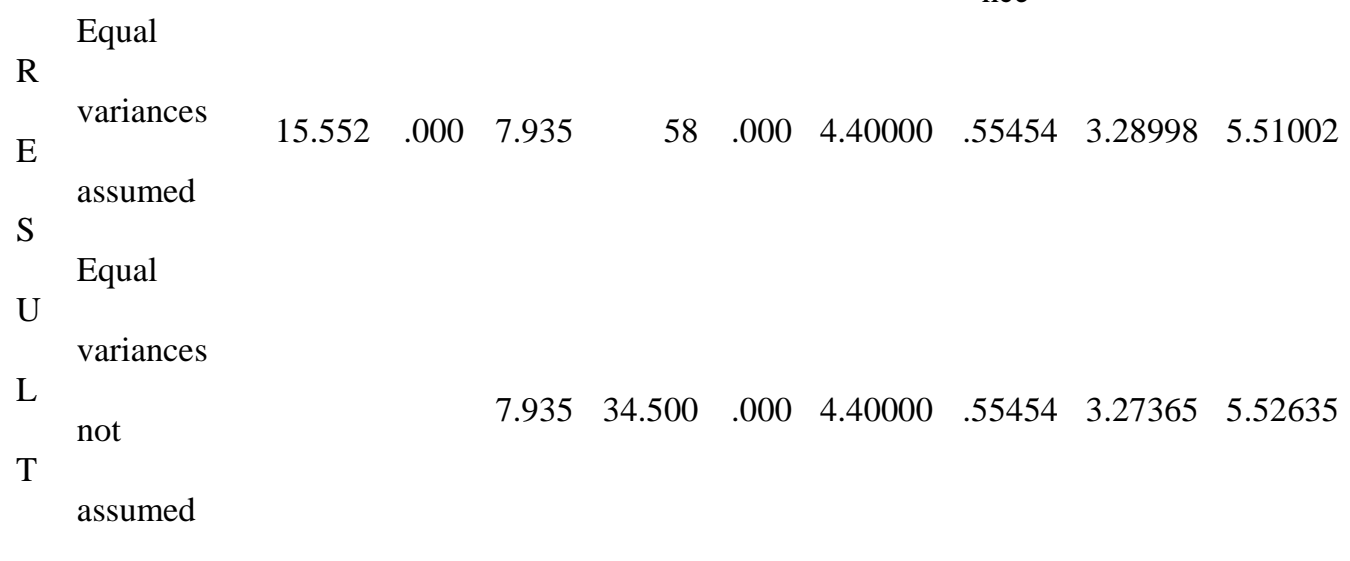

For enhanced acceptance about teaching strategies a test was conducted and analyzed. Investigations and conclusions are as under:

- The participants of the groups from class BS II at university level.

- They all were females.

- The participants were students and were analyzed in English compulsory class; the participants were grouped as group A and group B. Group A means the methodology of Bloom's taxonomy followed by the teacher and group B was taught by the teacher not following the Bloom's taxonomy.

- From the quantitative analysis of SPSS 20, data was analyzed through SPSS and entire five null hypotheses were rejected and it was established that Bloom's objective of teaching were rewarding and successful.

- The results revealed that students indicated effective language learning, if teaching would be incorporated Bloom's objectives of teaching. As Bloom's objectives of teaching levels was classified from lower order of thinking skills to higher order of thinking skills, so teacher uplifted students' critical thinking skills and accelerated language learning.

- Teaching strategy while teaching English language involve awareness of "how" of the language that directly linked with critical thinking. It was much more important to encourage students to think critically in English language classrooms.

- The deliberate attempt to teach English language incorporating critical thinking was very effective in building effective communication skills that further improved collaboration of the language learner and ultimately generated sensible and sensitive social citizens of Pakistan.

\section{DISCUSSION}

English language teaching was based on Bloom's objectives of teaching is very effective in enhancing critical thinking and language skills among the students at tertiary level. It was found that the graduate students at university in Karachi, Pakistan viewed that emphasis on critical thinking which helped them in enhancing English language learning. It was demonstrated that teaching based on Bloom's objectives of teaching had developed effective language learning among the students at university level. 
It was evident from the finding that teaching with Bloom's objectives of teaching was very significant and rewarding while teaching a language skill incorporating Bloom's objectives. The results revealed that students indicated effective language learning, if teaching would be incorporated Bloom's objectives of teaching. As Bloom's objectives of teaching levels was classified from lower order of thinking skills to higher - order of thinking skills, so teacher uplifted students' critical thinking skills and accelerates language learning. Teaching strategy while teaching English language involved awareness of "how" of the language that directly linked with critical thinking. It was much more important to encourage students to think critically in English language classrooms.

Thus, it was revealed through the study that teacher played the most vital role in the language learning. Therefore, it could be concluded that teaching effectively in a language classroom plays a major role in improving critical thinking and language learning of students. English language teaching had enhanced English communication skills through focused teaching strategies, presented by Bloom.

The main aim of education was to incorporate skills among student's that made them successful in their practical lives. Through incorporating effective teaching methodologies based on Bloom's objectives, this aim could be achieved, as critical thinking was beneficial in improving their effective English language learning. Thus, Bloom's taxonomy enabled the teacher to enhance their students' language learning. Thus, it was observed that teachers had a tendency to enhance English language. Learning through incorporating Bloom's objectives of teaching in language classrooms was very efficient. Cognitive process which was also known as thinking process was divided into two broad classes: Lower level of thinking and higher level of thinking. Higher order thinking was the type of cognitive processing that broadened students minds and wider their thinking ability. Higher order of thinking processes and described by the upper levels of hierarchies of thinking presented by Bloom's. The Scientific classification gave the continuum of psychological procedure beginning with recollecting and advancing through comprehension, applying, breaking down and

assessing to making. The subjective procedures in the upper portion of scientific categorization of Bloom's was alluded to as higher request of reasoning since they included English language student to participate in complex, contextualized language learning procedures to alter both information and unique thoughts in manners that portrayed their significance, It included students to settle on choices about basic issues, and to apply numerous measures so as to utilize those choices. When English language learners were engaged in higher order of thinking skills they would typically be required to explain, generalize, synthesis, interpret and construct innovative ideas. The results were predictable as students were thinking critically and it could be predicted what students might create if they were thinking critically.

In order to promote English language learning it was important that teachers must promote higher phase of thinking. Higher order of thinking skills was directly relevant with the teaching strategies. It was important that teaching methodology must follow 
Bloom's objectives of teaching. So, to achieve the goal of desired language learning was ideal to focus Bloom's objectives of teaching. In English language classroom it was the errand of an educator to give and guide them towards greatness in language yet language learning required significantly more than only recognition with the jargon and syntax of the language. It likewise included familiarity with how language worked to impact thinking, feelings and comprehension. It was the obligation of a language instructor to assist students with understanding how sentence structures affected significance, how importance as passed on, why various types of writings were utilized a specific circumstance and the job of correspondence.

The attempt to teach English language incorporating critical thinking was very effective in building effective communication skills that further improved collaboration of the language learner and ultimately generated sensible and sensitive social citizens of Pakistan.

Language learning was directly related with the emotive power. Language shaped the thinking, perception and emotional vacation to information. Effective teachers cared about their learners. They had friendly, mature rapport with their students and demonstrated caring. 'There was an old saying, you could lead a horse to water but you could not make it drink'. Unfortunately, some teachers had this view of leaners, believing that no matter what methodologies were represented to students some of them would not learn. But this was defeatist view of teaching that raised from the beliefs about students' lack of motivation, but it was very significant to consider the researches done on learners' psychology. The pages of psychology were crammed full with the experiments and discussions on the theories of learning, presented by Piaget, Vygotsky and many more. The view about leaner's psychology was suggested that all students could learn and succeeded, but not on the same day in the same way. It was the mastery of the teacher to provide learning opportunities.

\section{RECOMMENDATIONS}

Based on the results of this study, the researcher has forwarded following recommendations in order to uplift the standards of English language teaching and learning:

It is recommended that in order to be an effective English language teacher, it is important to undertake more training sessions.

It is important for the teachers to advance their qualifications.

The concept of keeping reflective journal is also praiseworthy.

It is good to be involved in enhanced professional and personal growth and being a teacher researcher it is good to be involved continuously in action research.

English language is the most important language in order to uplift the economy of Pakistan it is important to learn English language in order to be a part of developed country.

In order to upgrade economy and trade of our country it is important for our youth to learn English language as English has become lingua franca.

English is an international language, so teaching such as requires distinctive language teaching objectives and approaches. It is the time to prepare enthusiastic candidates for 
English language teaching sessions.

With the realization that Pakistan is an emerging country, it is necessary to provide prospective learners the awareness about the dominant role of English, in driving the economy of Pakistan. Crystal pointed out that English has attained the status of an international language, as it develops a special role that is recognized in every country. As critical thinking skill is a significant catalyst in English language learning. So such training sessions be conducted for teachers.

It is necessary to guide students about academic writing skills. In teaching and supervising the students about communication skills. It will make the students able to compete in all areas.

\section{REFERENCES}

AK, J., Bhatia, P. S., \& Sheikh, A. M. (2011). Professional Communication Skills. S. Chand Publishing.

Anil, B. (2017). Applying innovative teaching methods in a second language classroom. International journal of research in English education, 1. (1), 1-9.

Anthony, E. M (1963).”Approach, Method, and Technique” .ELT Journal.63-67.

Awan, G. A, Shafi, M. (2016). Analysis of Teaching Methods of English Language at government school of D.G. Khan City-Pakistan. An international peer-reviewed Journal, 26. 9-17

Ayres, P., Sawyer, W., \&Dinham, S. (2004). Effective teaching in the context of a grade 12 highstakes external examination in New South Wales, Australia. British Educational Research Journal, 30(1), 141-165.

Bhatti, A., Shamsudin, S., \& Said, S. B. M. (2018). Code-Switching: A Useful Foreign Language Teaching Tool in EFL Classrooms. English Language Teaching, 11(6), 93-101.

Blooms, B.S (ed.). Taxonomy of Educational Objectives.VO1.1: Cognitive Domain .New York: McKAy, 1956

Brown, H.D. (2004) Some practical thoughts about students- sensitive critical pedagogy. The Language Teacher, 28(7), 23-27

Burns, A.ss, Joyce, H., \&Gollin, S. (1997). I see what you mean. Using spoken discourse in the classroom: A handbook for teachers.

Busa, M.G. (2010).Sounding natural: improving oral presentation skills. Journal of Language value, 2, 51-67.

Chamot, A. (1995). Creating a community of thinkers in the ESL/EFL classroom. TESOL Matters, 5(5), 1-16.

Chang. M. (2011). Factors affecting the implementation of communicative language teaching in Taiwanese college English classes. Canadian Center of Science and Education, 4(2), 312.

Chapple, L., \& Curtis, A. (2000). Content-based instruction in Hong Kong: Student responses to film. System, 28,419-433.

Chien, C. (2014). Analysis of EFL teaching Methods for Taiwan University Students. Journal of Language Teaching and Research, 5. (5), 985-993.

Chung, G. (2014). A Study of Instructional Psychology on Grammar Translation Method from Chinese I-Ching. Journal of Studies in Social Sciences, 9 (11), 22-23

Clark, B.\& Clark, R. (1997). Las universidadesmodernas. Espacios de investigación y docencia.

Cochrane, T. (2009). Enhancing the oral presentation skills of engineering students: Technology to the rescue with the virtual-I presenter (VIP). Journal of American society for 
engineering education.

Cohen, L., Manion, L., \& Keithmorrison (2005). Research Methods in Education. London: Taylor \& Francis group publishers.

Cole,P\& Chan. L 1986. A New Perspective on Teaching Processes: paper presented at annual Conference of the Pacific Association for teacher Education, Perth Australia

Creswell, J.W. (2012). Educational research planning, conducting and evaluating quantitative and qualitative research. America: Pearson.

Davidson, B. (1994). Critical thinking: A perspective and prescriptions for language teachers. The Language Teacher, 18(4), 20-26.

Davidson, B. (1998). A case for critical thinking in the English language classroom. TESOL Quarterly, 32, 119-123.

Dörnyei, Z., (2011) Research Methods in Applied Linguistics New York : Oxford University press.

Effective. 2015 (9th edition). Oxford Advanced Learner Dictionary: Oxford University Press.

Elder, L. \& Paul, R. (1994) Critical thinking: Why we must transform our teaching. Journal of Developmental Education, 18(1), 34-35.

Ellis, R. (2012). Language teaching research and language pedagogy. John Wiley \& Sons.

English. 2015 (9th edition). Oxford Advanced Learner Dictionary: Oxford University Press.

Erkaya, O. R. (2005). Benefits of Using Short Stories in the EFL Context. Online Submission, 8.

ESL. 2015 (9th edition). Oxford Advanced Learner Dictionary: Oxford University Press.

Fang. F. (2010). A discussion on developing students communicative competence in college English teaching in China. Journal of Language Teaching and Research 1(2), 111-116.

Fritzley, V., \& Lee, K. (2003). Do young children always say yes to yes-no questions? A metadevelopmental study of the affirmation bias. Child development, 74(5), 12971313.

Gibbons, L. K., \& Cobb, P. (2016). Content-focused coaching: Five key practices. The Elementary School Journal, 117(2), 237-260.

Graff, W. (1985). Language and Learning Principles. Longmans Green and Co LTD. London, UK. (pp. 60-67)

Greene, G. (2003). Conversations with Graham Greene. Univ. Press of Mississippi.

Gregersen, T. S. (n.d). Language learning beyond words: Incorporating body language into classroom activities. Journal of reflections on English language teaching, 6, (1) 51-64.

Harmer, J. (2007). The Practice of English Language Teaching. England: Longman.

Harmer, J. (2008). How to teach English. ELT journal, 62(3), 313-316.

Hattie, J. (2012). Visible learning for teachers: Maximizing impact on learning. Routledge.

Hawkins, D. R. (2013). Power vs. force. Hay House, Inc.

Hedge, T. (2001). Teaching and learning in the language classroom (Vol. 106). Oxford, England: Oxford university press.

Jain, A.K., Pravin S.R., Bhatia and Sheikh.A.M. (2011). Professional communication skills. india: S.chand publishing.

Jones, S.E., \& Baron, C.D.L. (2002). Research on the relationship between verbal and non-verbal communication.

Kabilan, K.M. (2000) Creative and critical thinking in language classroom. Internet TESL Journal, 6/6.

Kalanzadeh, G. A., Michenari, N. A. N., and Bakhtiarvand, M. (2013). Perceived problems in using communicative language teaching (CLT) by EFL Iranian teachers. The International Journal of Language Learning and Applied Linguistics World, 2(3), 5-16.

Kerr,J.F (1969) Changing the Curriculum

Krathwohl, D. R., \& Anderson, L. W. (2009). A taxonomy for learning, teaching, and assessing: A revision of Bloom's taxonomy of educational objectives. Longman. 
Kusaka, L. L., \& Robertson, M.Beyond Language: Creating Opportunities for Authentic Communication and Critical Thinking. 14, 21-38.

Lane, J. (2012). Communication. United Kingdom: BPI worldwide.

Latham, G. P., \& Locke, E. A. (1991). Self-regulation through goal setting. Organizational behavior and human decision processes, 50(2), 212-247.

Leena, S. (2011). Communication skills. Mumbai: PHI learning private limited. Marie, C., \& and Lardner, M. (2002). What you speaks volumes. Journal of Michigan Bar,

Liaw, M. (2007). Content-Based Reading and Writing for Critical Thinking Skills in an EFL Context. English Teaching \& Learning, 31(2), 45-87

Lopez, D., Stupp, P., Gendell, M., \&Peng, S. (1984). Demographic projections of non-English language background and limited English proficient persons in the United States to the year 2000 by state, age, and language group. Rossyln VA: InterAmerica Research Associates.

Lumbanraja, P. (2016). : The effect of using Self-Directed Learning Method into student's speaking ability at eleventh grade students of SMA Parulian 1 Medan.

Mackey, A., \&Gass, S. M. (Eds.). (2011). Research methods in second language acquisition: A practical guide (Vol. 7). John Wiley \& Sons.

Mahyuddin, R., Lope Pihie, Z. A., Elias, H., \&Konting, M. M. (2004). The incorporation of thinking skills in the school curriculum. Kajian Malaysia, Jld, 22(2), 23-33.

Mareva, R., and Nyota, S. (2012). Structural or communicative approach: A case study of English Language teaching in Masvingo urban and peri-urban secondary schools. International Journal of English and Literature. 3(5), 103- 111.

Marmah, A. A. (2014). Students Perception about the lecture as the method of Teaching in Tertiary institutions. Views of students from college of technology education, Kumsai (coltek). International Journal of Education and Research, 2. (6), 601-612.

Nentl, N., \&Zietlow, R. (2008). Using Bloom's taxonomy to teach critical thinking skills to business students. College \& Undergraduate Libraries, 15(1-2), 159-172.

Nunan, D. (2012). Learner-centered English language education: The selected works of David Nunan. Routledge.

Omaggio, A. (1986). Teaching language in context.Heinle\&Heinle Publishers, International Thomson Publishing Book Distribution Center, 7625 Empire Drive, Florence, KY 41042.

Pandey, M., \& Pandey, P. (2014). Better English for better employment opportunities. International journal of multidisciplinary approach and studies, 1(4), 93-100.

Pica, T. (2000). Tradition and transition in English language teaching methodology System, 29, $1-18$.

Qizi, B. F. H. (2018). The use of critical thinking in EFL (English as a foreign language) classrooms. European science, (2 (34)).

Qualifications and Curriculum Authority (2001-2002).

Rahman, M. S., and Karim, S. M. S. (2015). Problems of CLT in Bangladesh: ways to improve. International Journal Education Learning and Development, 3(3), 75-87

Rahman, S. A., \&Manaf, N. F. A. (2017). A Critical Analysis of Bloom's Taxonomy in Teaching Creative and Critical Thinking Skills in Malaysia through English Literature. English Language Teaching, 10(9), 245-256.

Ramirez, R. A. V. (2010, August). Handing multiple communications sessions for the next generation of wireless networks. In 2010 Fifth International Conference on Systems and Networks Communications (pp. 249-254). IEEE.

Ramsden, P. (2003). Learning to Teach in Higher education. (2nd ed.), London, Routledge Falmer.

Rehman, M.M. (2010).Teaching oral communication skills: A Task-based Approach. Journal of ESP world, 9, 1(27). 
Reynoso, L. C. (2019). English Teachers' Effectiveness and Students' English Proficiency at Selected Colleges in Dili, East Timor: Input for Enhancement Programs. English Language Teaching, 12(10).

Rezaei S, D. A. (2011). Critical Thinking in Language Education. Journal of Language Teaching and Research, 769-777

Shirkhani, S., \&Fahim, M. (2011). Enhancing critical thinking in foreign language learners. Procedia-Social and Behavioral Sciences, 29, 111-115.

Simpson, J. G., Furnace, J., Crosby, J., Cumming, A. D., Evans, P. A., David, M. F. B., ... $\&$ McPhate, G. F. (2002). The Scottish doctor--learning outcomes for the medical undergraduate in Scotland: a foundation for competent and reflective practitioners. Medical teacher, 24(2), 136-143.

Sloboda, J. (1986). What is skill. The skilful mind: An introduction to cognitive psychology. Open University Press, Milton Keynes.

Spady, W. G. (1994). Outcome-Based Education: Critical Issues and Answers. American Association of School Administrators, 1801 North Moore Street, Arlington, VA 22209

Taba, H. (1993). Elaboración del curriculum. Troquel Editorial.

Tanner, D., \& Tanner, L. N. (1980). Curriculum development: Theory into practice. New York: Macmillan.

Taralunga, E. (2006). Concepts on the methodology of teaching English, the economic journal of Takasaki City University of economics, 48 (3), 169-188

Tare, N. (2016). Effective Methods of Teaching and Learning English as the Second Language (E2L). Epitome: International journal of Multidisciplinary Research, 2 (12), 45-49.

Tarvin, W., \& Al-Arishi, A. (1991). Rethinking communicative language teaching: Reflection and the EFL classroom. TESOL Quarterly, 25(1), 9-27.

Teaching Methodology. 2015 (9th edition). Oxford Advanced Learner Dictionary: Oxford University Press.

Techniques. 2015 (9th edition). Oxford Advanced Learner Dictionary: Oxford University Press.

Thomson, N. (2012). Language teaching strategies and techniques used to support students learning in a language other than their mother tongue. Executive summary

Tourish,D.,\&Hargie,O (2004) .Key issues in organizational communication (pp.205210).London :Routledge

Ur, Penny. (1984). Teaching Listening Comprehension. Cambridge: Cambridge University

Valanayagem, E.G. (1994). Teaching Technology for College Teachers. New Delhi. Sterling Publishers.

Van Duzer, T. (1997). Fields and waves in communication electronics. John Wiley \& Sons.

Vdovina, E., \&Gaibisso, L. C. (2013). Developing critical thinking in the English language classroom: A lesson plan. ELTA journal, 1(1), 54-68.

Vilanilam, J.V. (2000). More Effective communication. London: Response books

Vilanilam, J.V. (2000). More Effective communication. London: Response books.

Walia, D. N. (2012). Traditional teaching methods vs. CLT: A study Frontiers of Language and Teaching, 3, 125-131 